\title{
Local Gazetteers Research Tools: Overview and Research Application
}

\author{
Shih-Pei Chen, Kenneth J. Hammond, Anne Gerritsen, Shellen Wu and Jiajing Zhang
}

doi: $10.1017 /$ jch.2020.26

\begin{abstract}
This article gives an overview of the Local Gazetteers Research Tools (LoGaRT), including its development, technical features, methodology, and examples of research applications by members of the Tu 圖 working group. The use of LoGaRT is illustrated with four brief introductions to projects that draw on visual materials from the local gazetteers, including ritualrelated illustrations, city layout maps, and maps with western cartographic features. See the websites for more detailed information on LoGaRT and other research projects using it. ${ }^{1}$
\end{abstract}

Keywords: locality; digital humanities; urban space; ritual illustrations; chorographic maps

\section{Purpose}

Local Gazetteers (difangzhi 地方志) have been major sources for studying historical China: they were compiled to describe local administrative units. Local governments have compiled and updated them ever since the twelfth century, and they cover both well-populated and less-well-populated regions such as border zones. Most importantly, they contain consistent kinds of information about localities across geographical regions and time periods. Information at this granularity is not easy to find elsewhere.

There are more than ten thousand distinct titles of local gazetteers in libraries, museums, and archives around the world. Many of them have been digitized as both scanned images and searchable full texts, enabling unprecedented opportunities to study this genre from a collective perspective-treating the genre of local gazetteers as a conceptual database for historical inquiry. Most local gazetteers with searchable full text are accessible to scholars through commercial vendors. ${ }^{2}$ Despite the useful reading environments that commercial databases provide, the lack of analytic tools in these online

\footnotetext{
${ }^{1}$ Shih-Pei Chen, Calvin Yeh, and Sean Wang, “LoGaRT: Local Gazetteers Research Tools," Max Planck Institute for the History of Science, accessed September 5, 2019, https://www.mpiwg-berlin.mpg.de/ research/projects/logart-local-gazetteers-research-tools. Shih-Pei Chen, Dagmar Schäfer, and Qun Che, "Local Gazetteers Working Group," Max Planck Institute for the History of Science, accessed September 5, 2019, www.mpiwg-berlin.mpg.de/research/projects/departmentSchaefer_SPC_MS_LocalGazetteers.

${ }^{2}$ There are mainly three players: Eruditon (Airusheng 爱如生), with its 4,000 titles in the Zhongguo fangzhi ku 中國方志庫 issued in two batches in 2013 and 2016, was the first in the market with a stable user interface that supports different ways of search including full-text search, a good reading interface with parallel display of a scan of the original and transcribed text and more. Diaolong 雕龙 offers another 4,000 titles. EastView joined the market later with around 7,000 titles (only a portion of which include searchable digital texts) sourced from National Library.

(c) Cambridge University Press 2020. This is an Open Access article, distributed under the terms of the Creative Commons Attribution-NonCommercial-NoDerivatives licence (http://creativecommons.org/licenses/by-ncnd/4.0/), which permits non-commercial re-use, distribution, and reproduction in any medium, provided the original work is unaltered and is properly cited. The written permission of Cambridge University Press must be obtained for commercial re-use or in order to create a derivative work.
} 
collections means the commercial products are not so helpful in terms of collective understanding and analysis of the genre.

\section{Method: Using Local Gazetteers with a Collective Lens}

In 2014, the Max Planck Institute for the History of Science started a research project to study the nature of local knowledge and the role of local gazetteers in Imperial China. The large number of digital gazetteers led us to develop computational methods for effective research. LoGaRT, the Local Gazetteers Research Tools, were first developed in 2016 for this purpose. The underlying philosophy is to treat all the gazetteers available in digital format as a conceptual database for historical inquiries in order to ask questions at larger scales-scales not necessarily bounded by geographical regions, time periods, or individual effort. In other words, LoGaRT helps scholars study digital gazetteers with a collective lens.

\section{Search and Visual Overview}

LoGaRT is aimed at facilitating "collective analyses" by enabling scholars to quickly grasp the overview of any search result. In LoGaRT, scholars can conduct searches at the three levels of book, chapter/section, and page text and can explore the composition of the search results with visual analytics. For example, in Book Search scholars can see both a list of book titles that are currently linked with LoGaRT and the dates of the editions and the places the gazetteers document. Figure 1 shows the composition of 3,999 digital gazetteers from Erudition's Zhongguo fangzhi ku in terms of their geographical, dynastic, chronological, and administrative distributions. Such a utility helps scholars to understand the basis of their studies.

The same visual analytic tool is linked to any search at book, section, or page text levels, providing scholars a way to quickly grasp the overview of any search result to understand its composition. ${ }^{3}$ Although LoGaRT's Page Text Search is very similar to general full text search, its Section Search is a feature unique among all current local gazetteer databases. ${ }^{4}$ LoGaRT's engine searches for section titles based on our work to add a three-level hierarchical Table of Contents to our database. ${ }^{5}$ Figure 2 shows the Table of Contents editing interface in LoGaRT. This massive effort has proven to be very worthwhile-scholars can now search by section titles to identify which local gazetteers include those specific sections, or they can bring all sections on the same topic together regardless of edition, time, and place. In Ian Matthew Miller's case,

\footnotetext{
${ }^{3}$ This visual analytic tool, named LGMap, is customized from the open source tool PLATIN (Place and Time Navigator). It allows scholars to upload data with temporal and geospatial attributes in a tabular format, either Comma Separated Values (CSV) or Microsoft Excel format, and then it creates visual representations of the uploaded data in a map, a timeline, and user-specified pie charts. Users can interact with any of the three visual components to see more fine-grained composition of the data. See examples and source code at PLATIN: Place and Time Navigator-A tool for the interactive visualization of geospatial and temporal data, http://platin.mpiwgberlin.mpg.de/. For a detailed use case of this feature working with full text search see Shih-Pei Chen, "Remapping Locust Temples of Historical China and the Use of GIS 重制陳正祥之蝗神廟分佈圖與淺談 GIS 的使用, Review of Religion and Chinese Society 3.2 (2016), 149-163. doi:10.1163/22143955-00302002.

${ }^{4}$ One issue that scholars should pay attention to is the way that each databases counts "matches" or "hits." While some databases use the total number of occurrences of the search term as the number of hits, LoGaRT uses the total number of pages in which the search term(s) appear as its result number. This number is smaller than the number of all occurrences.

${ }^{5}$ This work was done through a collaboration between MPIWG and the Nanjing University of Information Technology and Engineering. CAO Ling led a team of graduate students who manually typed in the section titles, start and end page numbers, and levels in the hierarchy.
} 


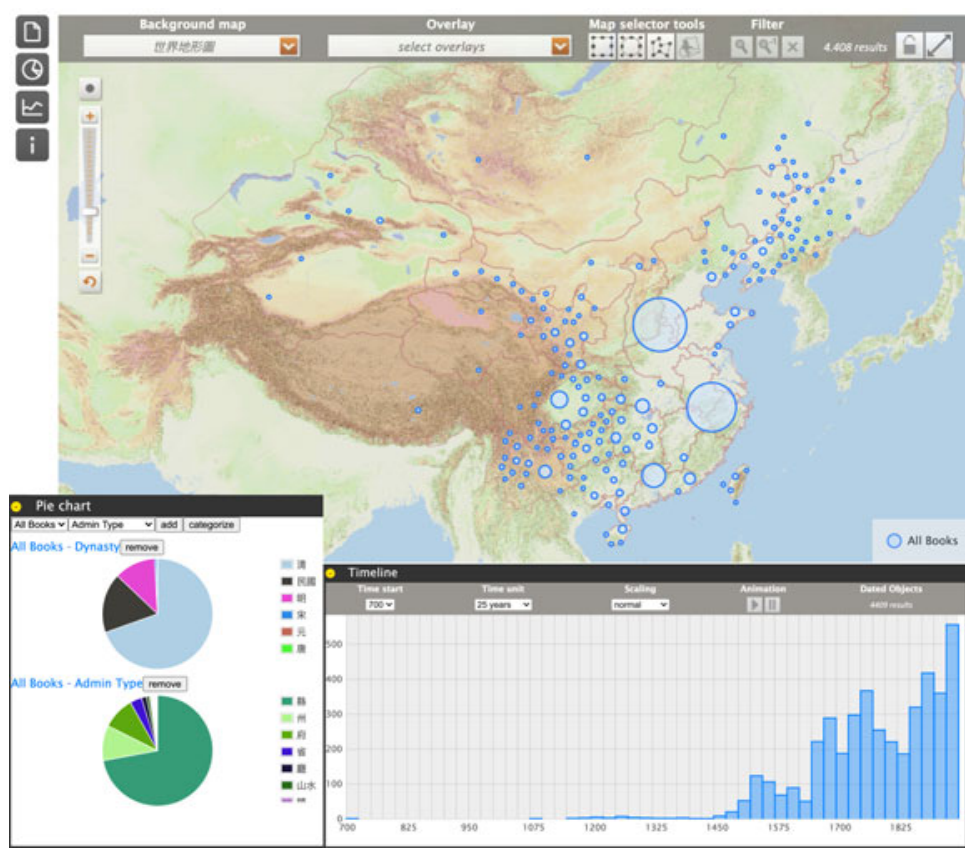

Figure 1. LoGaRT's visual analytics interface, showing the geographical, dynastic, chronological, and administrative distributions of the 3,999 titles included in Zhongguo Fangzhi Ku

searching for logging (muzheng 木政) in Section Search enabled him to discover when and where logging was important enough to warrant a section. ${ }^{6}$ Scholars can combine Section Search with Page Text Search to weed out irrelevant full-text search results. The display of section titles in Page Text Search results is informative for understanding the contexts of mentioned keywords.

\section{Text-Tagging: Data Collection Across Local Gazetteers}

Beyond search and visual analytics, LoGaRT also comes with a text-tagging interface to help scholars work more effectively with structured texts. Gazetteers commonly organize information in lists: of buildings, local products, officials, etc. Text-tagging makes up for the difficulty computers have with finding similar structures across different gazetteers. An example is the listing of book titles in Figure 3 from the School section (xuexiao 學校志) of the Guangxu Jishui county gazetteer (吉水縣志). ${ }^{7}$ The core functionality of LoGaRT's tagging interface was originally developed in 2013 to extract posting records in the Posting sections (zhiguan 職官志) for the China Biographical

\footnotetext{
${ }^{6}$ See more analyses in Ian Matthew Miller, "Regional Patterns of Forestry in Four Maps," Roots and Branches: Growing Histories from the Ground Up, December 18, 2017, https://medium.com/roots-andbranches/regional-patterns-of-forestry-in-four-maps-eb3d8c2237e0.

${ }^{7}$ This example is provided by Joseph Dennis, who has been using LoGaRT in a study of school library collections in the Ming, Qing, and Republican China. See his "School Library Book Collections in Ming, Qing, and Republican China," accessed April 28, 2020, Max Planck Institute for the History of Science, www.mpiwg-berlin.mpg.de/research/projects/school-library-book-collections-ming-qing-and-republicanchina- 0 .
} 


\begin{tabular}{c|ccccc} 
Seq No. & Section Name & Start Page & End Page & Level \\
\hline 1 & 八閩通誌序 & 1 & - & 9 & 1 \\
\hline 2 & 八閩通誌序 & 10 & - & 16 & 1 \\
\hline 3 & 八閩通誌凡例 & 17 & - & 23 & 1 \\
\hline 4 & 八閩通誌目錄 & 24 & - & 49 & 1 \\
\hline 5 & 八閩通誌卷之一 & 50 & - & 114 & 1 \\
\hline 6 & 地理 & 50 & - & 114 & 3 \\
\hline 7 & 建置沿革 & 51 & - & 114 & 3
\end{tabular}

Figure 2. The Table of Contents Editor in LoGaRT, hosting sections titles, begin and end page numbers, and up to three levels of content hierarchy

Database (CBDB). ${ }^{8}$ MPIWG continued to improve this function after 2014 , making it a flexible tool for tagging texts and extracting data from any structured section. By tagging, we refer to the action of a user to highlight a segment of text and specify the attribute it represents in the text, normally by giving it a semantic label defined by the user; in this case from Joseph Dennis it would be book title, number of volumes, distributed by, and so on. Figure 4 shows part of the digital text of Figure 3 as tagged by Dennis. Any tagged text in LoGaRT can then be converted to a data table, as shown in Figure 5.

LoGaRT's tagging interface comes with a set of functions supporting the tagging workflow, from defining a tagging Topic, defining corresponding Tags, to SmartRegex, a toolkit helping scholars to define "regular expressions" to capture re-appearing text patterns and to automate tagging. All these functions help scholars apply the same settings (in Topics) to texts with similar contents and structure, which might have been identified through Section Search or Page Text Search. By tagging with LoGaRT, scholars are able to collect similar kinds of information across local gazetteers to answer questions at larger scales than before. After seeing several historians using LoGaRT, we also realized that tagging (in particular, structured texts) helps scholars to deep-read texts in a very different way from reading to understand-it elevates scholars' understanding even of texts they have read several times, by paying more

\footnotetext{
${ }^{8}$ This work was sponsored by the China Biographical Database project at Harvard University. See Weiqian Peng, Hui Cheng, and Shih-Pei Chen, "Cong quan wen dao biao ge: di fang zhi zhi guan zhi zhong zi liao zhi ban zi dong xie qu.” 從全文到表格 : 地方志職官志中職官資料之半自動擷取 [From text to data: extracting posting data from Chinese local gazetteers], Shu wei dian cang yu shu wei ren wen 數位典藏與數位人文, 1 (2018), 79-125. doi:10.6853/DADH.201804_1.0004.
} 
Figure 3. The first page of the list of school library collection reported in the Guangxu period Jishui county gazetteer (1875). Image credit Zhongguo Fangzhi Ku

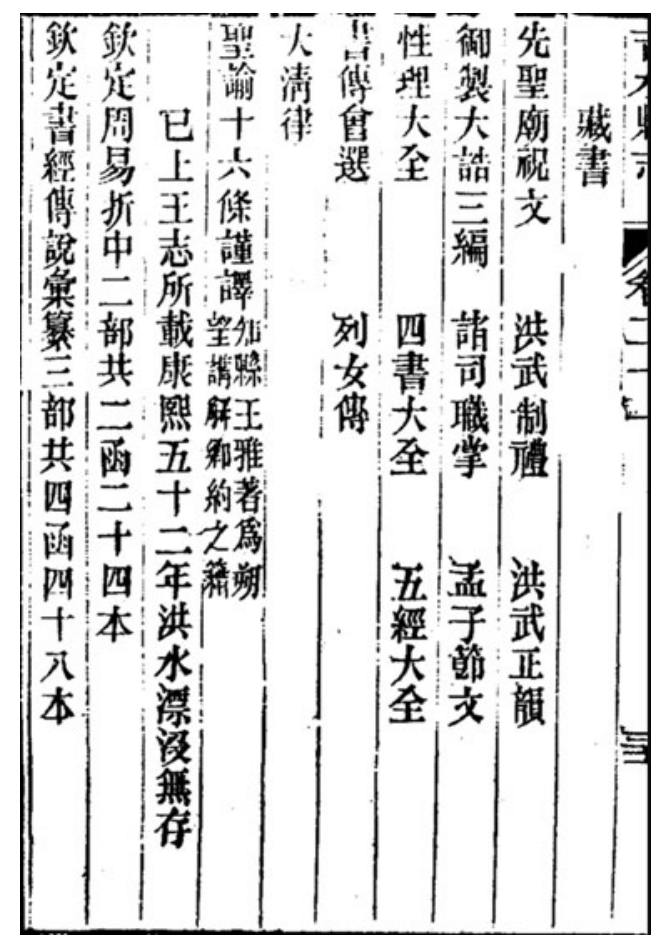

\section{【892】}

\begin{tabular}{|c|c|c|c|c|c|}
\hline 〈吉水縣學〉 & 〈學制〉 & 〈藏書〉 & 〈康熙五十二年洪水漂没無存〉 & 〈欽頒〉 & 先聖廟祝文 \\
\hline 水縣學〉 & 〈學制〉 & 〈藏書〉 & 〈康熙五十二年洪水漂没無存〉 & 〈欽頒〉 & 洪武制禮 \\
\hline 學〉 & 〈學制〉 & 〈藏書〉 & 五十二年洪水漂 & 頒〉 & 正韻 \\
\hline & 〈學制〉 & 〈藏書〉 & 十二年 & 須〉 & 三編 \\
\hline 水縣學〉 & 〈學制〉 & 〈藏書〉 & 〈康熙五十二年洪水漂治 & 頒〉 & \\
\hline
\end{tabular}

Figure 4. The corresponding digital text of Figure 3, with scholarly tagging. Each color represents a semantic label defined by the scholar, such as book title, number of volumes, distributed by

attention to the structures of knowledge implicit in the organization of information in a gazetteer.

\section{Research Application: the $T u$ 圖 Working Group as an Example}

Nearly forty scholars have visited MPIWG to use LoGaRT in their research projects in the past four years. Some of them have published results already and others are in preparation. The website gives lists of individuals and research projects. Most LoGaRT research focuses on textual information. Although the local gazetteers is mainly a text genre, it includes visual materials, mostly maps and spatial illustrations in the fore matter of gazetteers, and occasionally images accompanying particular texts. LoGaRT's Tu-related functions help scholars discover where images are and what 


\begin{tabular}{|c|c|c|c|c|c|c|c|c|c|c|c|}
\hline Count & Book ID & Book Name & Section Name & Book Year & Page No. & 書 & 卷數 & 刊發 & 存軼 & 段題 & 書位 \\
\hline 1 & 36766 & 吉水縣志 & 藏書 & 1875 & 892 & 先聖廟祝文 & & 敛頒 & 康熙五十二年洪水漂没無存 & 學制;藏書 & 吉水縣學 \\
\hline 2 & 36766 & 吉水縣志 & 藏書 & 1875 & 892 & 洪武制禮 & & 欽頒 & 康熙五十二年洪水漂没無存 & 學制;藏書 & 吉水縣學 \\
\hline 3 & 36766 & 吉水縣志 & 藏書 & 1875 & 892 & 洪武正䫓 & & 敛頒 & 康熙五十二年洪水漂没無存 & 學制;藏書 & 吉水縣學 \\
\hline 4 & 36766 & 吉水縣志 & 藏書 & 1875 & 892 & 御製大誥 & 三編 & 欽頒 & 康熙五十二年洪水漂没無存 & 學制;藏書 & 吉水縣學 \\
\hline 5 & 36766 & 吉水縣志 & 藏書 & 1875 & 892 & 諸司職掌 & & 敛頒 & 康熙五十二年洪水漂没無存 & 學制;藏書 & 吉水縣學 \\
\hline
\end{tabular}

Figure 5. The data table converted by LoGaRT based on the tagged text in Figure 4 
kind of information they depict, and thus to study the roles of visual materials in knowledge production and transmission in Imperial China.

The $T u$ Group brought in four scholars with research projects that used visual materials. With LoGaRT they identified 63,497 pages with images (PWI) in the 3,999 titles in Erudition's Zhongguo fangzhi ku and helped us identify needed functions for researching images. Each scholar developed a collection of pages, saved as a CSV file, listing the identifying number, book title, administrative unit, dynasty and reign period, year of publication and the year of the edition, as well as the latitude and longitude of the location associated with the gazetteer.

Once a collection has been developed, the individual image pages can be displayed using a "carousel" function, which allows the researcher to scroll quickly through the image set (Figure 6). This facilitates the rapid review and comparison of images. Each image can then be tagged with terms from a list of seventeen terms developed by the researchers, allowing for the creation of subsets within the original collection.

LoGaRT also allows several forms of graphic display of information. For example, LoGaRT collections can be geovisualized in CHMap developed by Nung-yao Lin, which displays a map that shows the locations of pages with images and the number of pages located within a given locality. ${ }^{9}$ This can be scaled up or down to provide greater detail or a broader overview (Figure 7). A statistics function displays quantitative information such as the number of pages within a given reign period, or the distribution of pages by province. Statistical information can be displayed as a bar chart, line chart, or pie chart. These features allow for the analysis of patterns within the dataset.

The brief reports below show how the tool has been applied in practice. ${ }^{10}$

\section{Anne Gerritsen: Representing Ritual in Local Gazetteers}

There are a significant number of non-spatial images in gazetteers, varying widely from agricultural implements to human figures, and from animals and plants to graphs, charts and photographs. Once they were tagged it became possible to organize them. The largest sub-group are images related to ritual: musical instruments and other implements used in ritual performances, depictions of human figures holding a feather plume in various ritual postures, charts that specify who and what should be positioned where during ritual performances, and so forth. The ritual postures usually appear in sets of twenty-four images in the gazetteers, while the musical instruments and ritual implements generally appear in less regular sets, ranging from small collections of five or six implements to extensive series of more than forty objects.

The 1756 gazetteer of Xiangtan county in Hunan illustrates this. ${ }^{11}$ There are thirtyfive pages depicting ritual implements, including the mountain vessel (shanzun 山尊) for offering wine depicted in Figure 8. These are followed by seventeen pages depicting

\footnotetext{
${ }^{9}$ For CHMap's stand-alone version and further information on basemaps, see Qun Che, Shih-Pei Chen, and Nung-yao Lin, "The WebGIS Platform of Historical Maps of China," Max Planck Institute for the History of Science, accessed September 5, 2019, www.mpiwg-berlin.mpg.de/research/projects/webgis-platform-historical-maps-china.

${ }^{10}$ These works are based upon research conducted while affiliated with the Max Planck Institute for the History of Science, and sources were made available during this affiliation via Staatsbibliothek zu Berlin's CrossAsia portal.

${ }^{11}$ Ouyang Zhenghuan 歐陽正煥 and Lu Zhengyin 呂正音, eds., Xiangtan xian zhi 湘潭縣志, Harvard-Yenching Library Chinese Local Gazetteers Digitization Project- Shan ben fang zhi (1756, n.d.), accessed 9 August 2019.
} 


\section{LoGaRT B Books E Sections Page Texts}

Q 2 PWI

:E Image Group: 1. All images

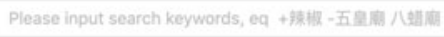

Q 8

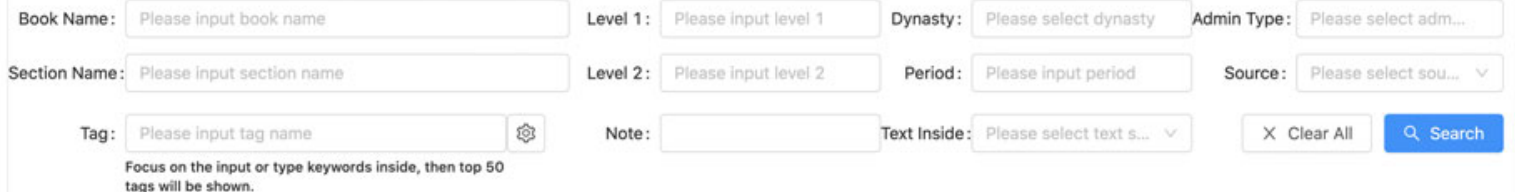
Focus on the input or type keywords inside, then top 50

Data Statistics Table Carousel $\square$ All

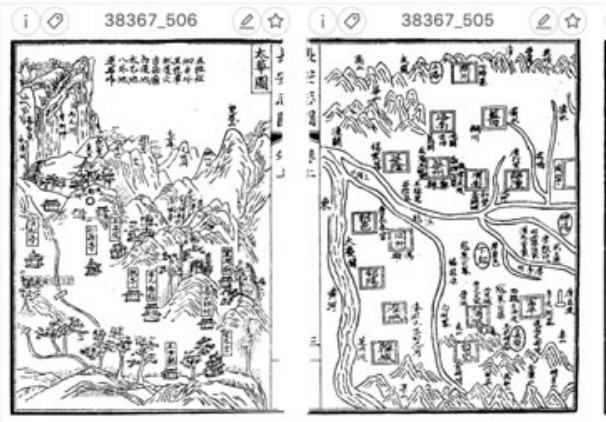

\begin{tabular}{|l|l|l|l|l|l|l|l|l|l|}
\hline 1 & 2 & 3 & 4 & 5 & $\cdots$ & 2713 & $>$ & $25 /$ page
\end{tabular}

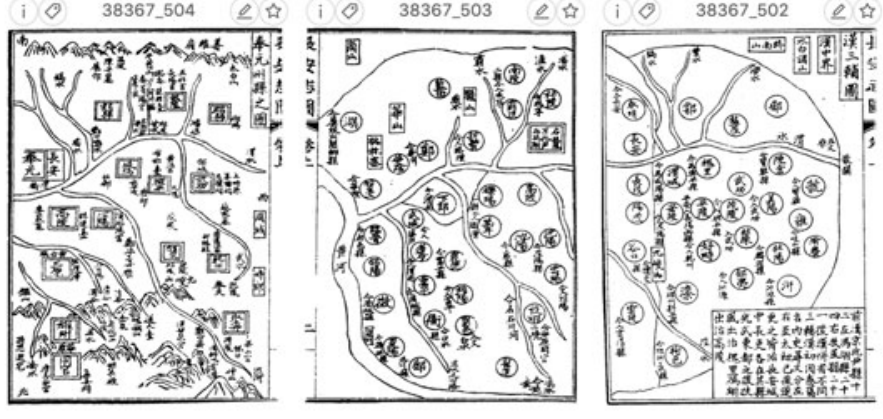

」To CSV

Figure 6. LoGaRT's carousel function 


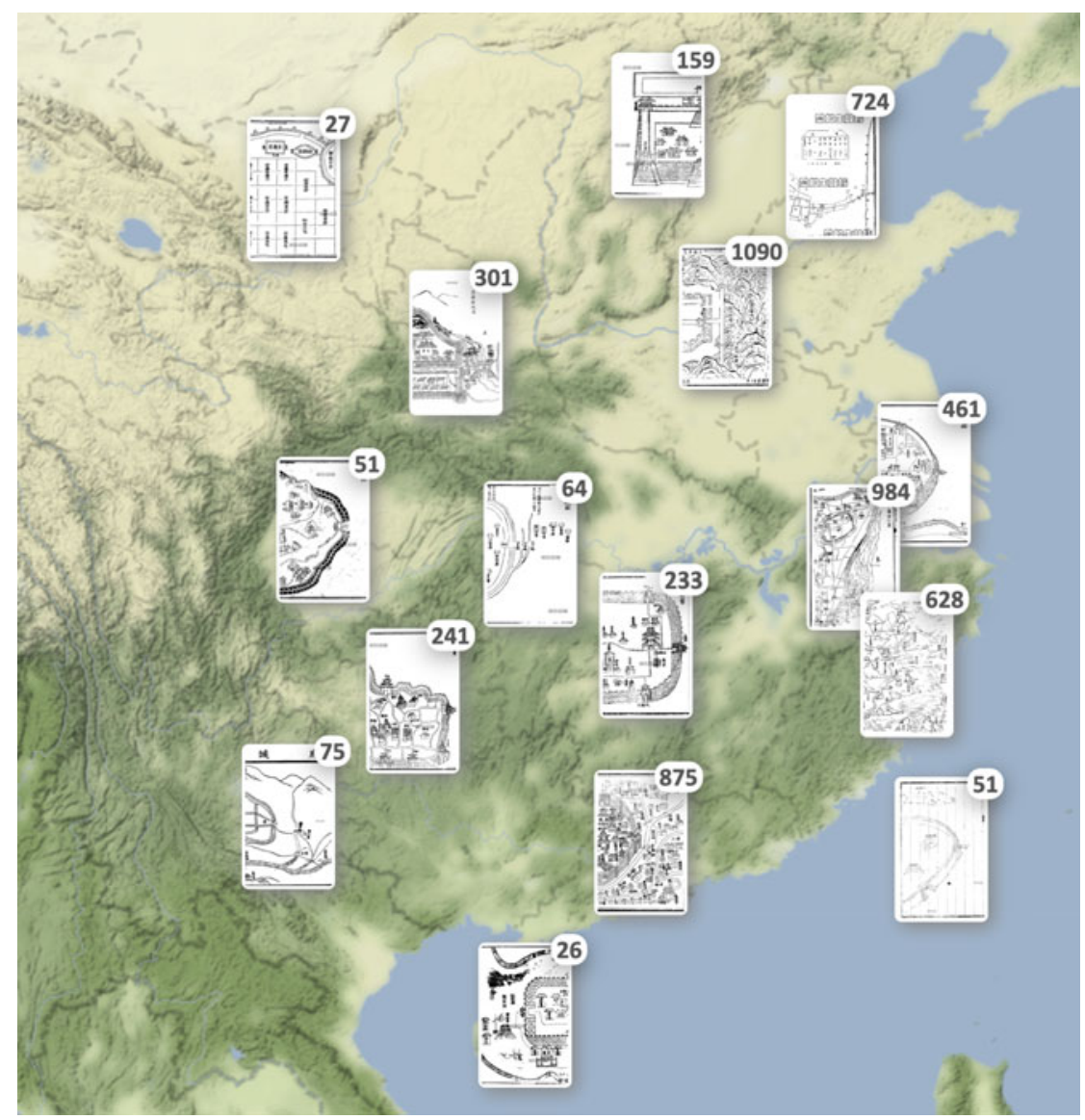

Figure 7. Geovisualization of LoGaRT image collection in CHMap

twenty-one separate musical instruments and stands for banners and flags. Finally, there are twenty-four pages with ritual postures, each with four separate postures (see Figure 9), as well as a page depicting the feather plume ( $d i$ 翟) and flute ( $y u e$ 䈁) held in the left and right hands, respectively.

LoGaRT functionality allows for various kinds of analysis of this visual material. We can identify when these sets of images related to ritual start to appear in the gazetteers (in Qing especially in gazetteers produced during the Qianlong, Tongzhi and Guangxu reign periods), and where they did (Hunan gazetteers, of which the Xiangtan gazetteer is one, stand out for extensive sets of ritual materials). More fine-grained analysis allows us to identify subgroups within the larger sets. For example, amongst the depictions of musical instruments is a $y u$ 敔, a wooden tiger, reclining on a platform or base, with spikes along which the player runs a wooden drumstick (zhen 㼳), as depicted in Figure 10. The percussive sound of this instrument usually indicates the end of the musical performance. The wooden tiger is usually part of the musical instrument series, but variation in the representation of the $y u$ suggests there was not a single but several sources for these images. 


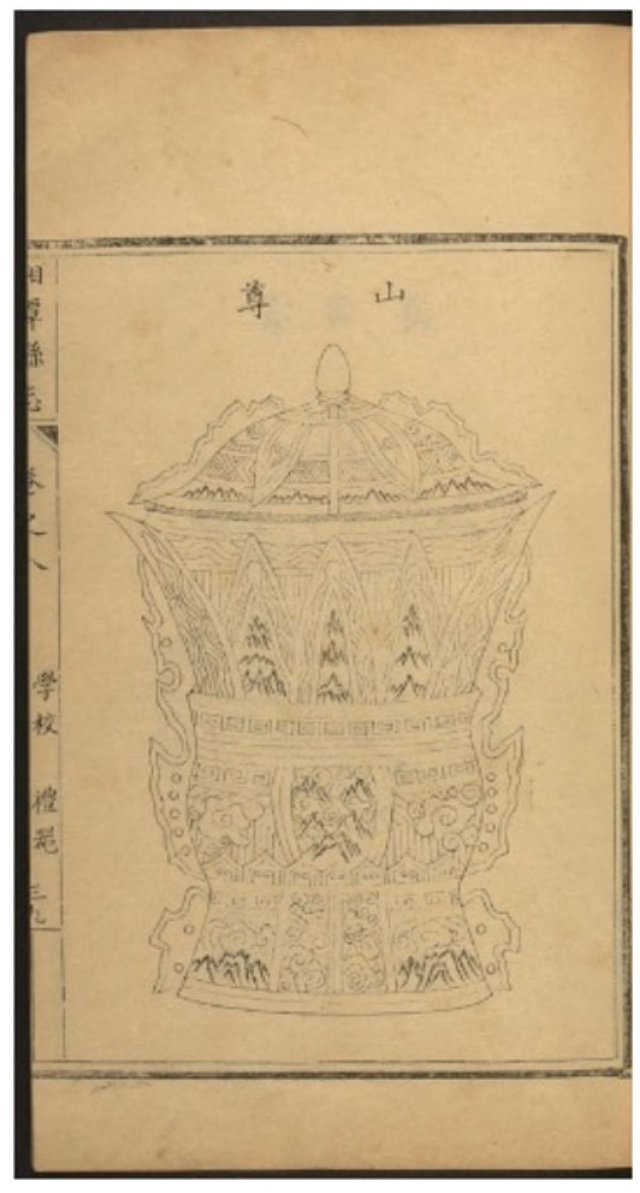

Figure 8. One of the ritual vessels included in Xiangtan xianzhi (1756) 8.38b-39a. HarvardYenching Library Chinese Local Gazetteers Digitization Project

\section{Ken Hammond: Visual Representations of Urban Space}

How were cities and towns mapped and visually represented from the Song through the Ming? An initial search with LoGaRT generated a set of 4,200 pages with images. It took several months to tag them, with most pages being excluded as not being places, or being of larger (e.g. counties) or smaller (e.g. schools) units. After a final examination there was a set of 235 maps of cities and towns, all but one from the Ming. The CHMap function showed that the majority of these came from the Jiangnan region, and that images of urban places decrease dramatically as one moves away from the coast and out to the perimeters of the empire. LoGaRT does not eliminate the need for reading and inspection, but it dramatically enhances the researcher's ability to rapidly identify the visual materials relevant to one's study, and it makes the aggregation and display of that material a much easier process.

\section{Shellen Wu: Frontier Settlements and Modern State Building in Late Imperial and Republican China}

Maps are the largest category of images in gazetteers. In this case the goal was to see changes in the content of maps from roughly the mid-nineteenth century to 1949 . 
Figure 9. Four of the 96 postures in Xiangtan xianzhi (1756) 8.69b-70a. HYL Chinese Local Gazetteers Digitization Project

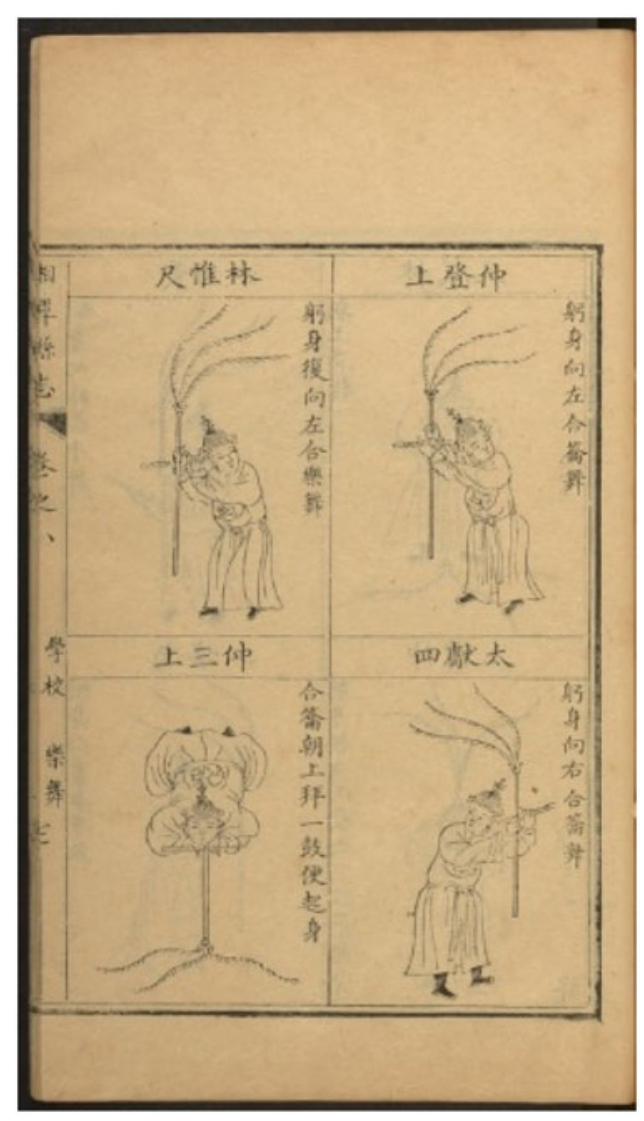

LoGaRT allowed narrowing the search to within the 10,000-image limit of most of its GIS and statistical functions.

Features appear in local gazetteers that have already been widely adopted by local elites, making the content of gazetteers evidence for the acceptance of certain ideological and conceptual change, in this case the spread of science in China as seen through maps and images. The result of this research would take the transmission and spread of science out of the treaty ports and missionary schools to map a new atlas of science in modern China.

For example, beginning in the late Qing period in the 1900s, city maps still look very similar to maps from earlier periods but, in addition to temples, schools, and benevolence halls, they show the location of police stations, girls' schools, and other new institutions such as agricultural experimental stations. Republican period maps sometimes contain information about the map-maker. Many of the Republican maps follow Western mapping conventions and contain features like a compass rose and altitude lines. Agricultural experimental stations, in particular, proved tremendously popular with late imperial literati, Qing officials, and, later, revolutionaries and reformers. Maps and images from the Yunnan Dali County Gazetteer (Dali Xianzhi Gao 大理縣志稿, 1916) illustrate this. It contains a sophisticated four-page series of contour maps of Dali port, as well as a city map that features schools and the agricultural experimental zone. Both the editor-in-chief and the compiler were prominent revolutionaries in the Xinhai Revolution. The 


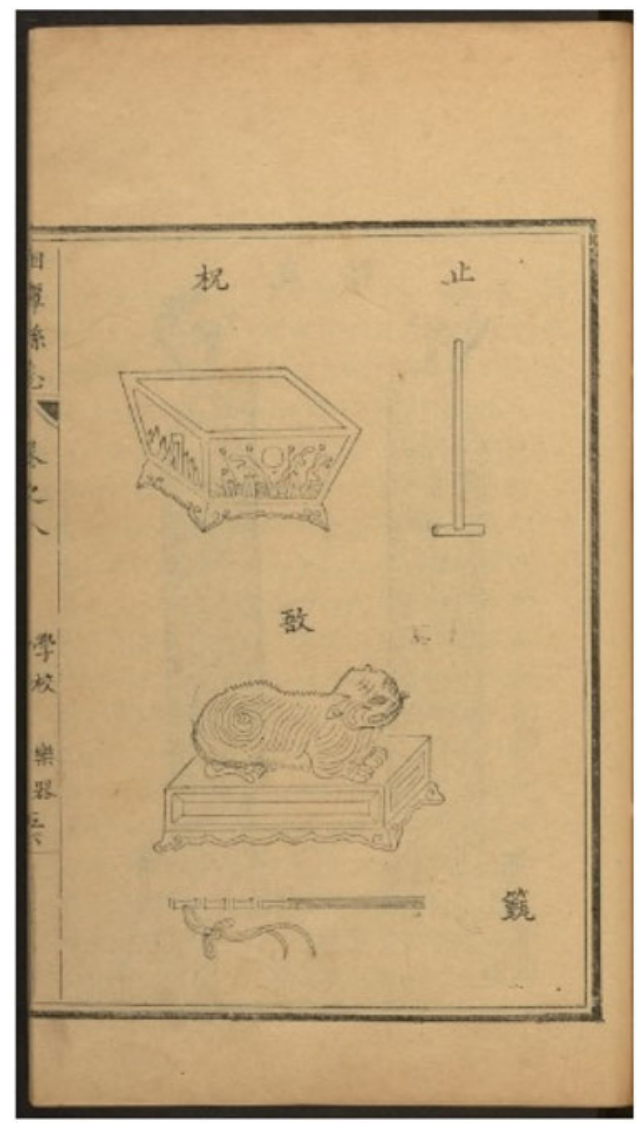

Figure 10. Two of the musical instruments included in Xiangtan xianzhi (1756) 8.55b-56a. HYL Chinese Local Gazetteers Digitization Project

editor-chief, Zhang Peijue, was an early member of Sun Yatsen's Revolutionary Alliance, the Tongmenghui. Zhang was executed in 1915 following his arrest by the Yuan Shikai government and died a martyr of the revolution. The chief compiler, Zhou Zonglin, was an educator and principal of a high school and teacher's college in Dali. He too had joined in the Xinhai Revolution. The biographies of the two men and the contents of the Dali County Gazetteer suggest that New Learning and the spread of the sciences accompanied a variety of advocates to their hometowns and villages, far from the major treaty port cities. By the late Qing and early Republican period, local elites from Yunnan in the southwest to Jilin in the northeast had embraced reforms and established schools as the bases from which to spread their ideas. This is one instance of how LoGaRT may change our current conception of the spread of science and revolution in modern China. LoGaRT's image search functions allow the use of gazetteers for new avenues of research in Chinese history and the history of science.

\section{Zhang Jiajing: Research on the Longitude and Latitude of Guangdong Provincial Gazetteer Maps in the Qing Dynasty}

During the late Qing period Chinese cartographers started to adopt Western cartographic techniques and their maps began to make use of projection, longitude, and 


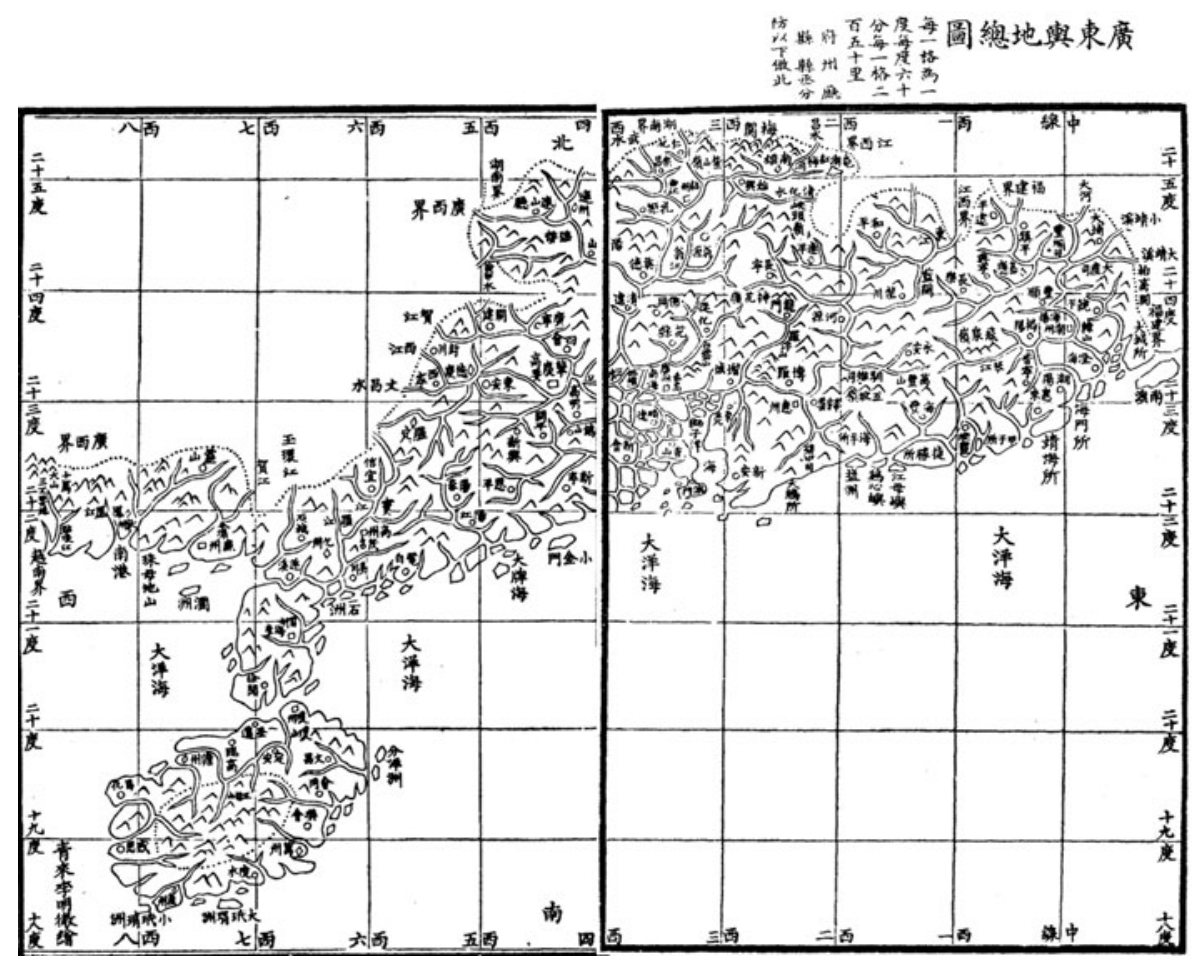

Figure 11. (Daoguang) Guangdong Yudi Zongtu. (Daoguang) Guangdong Tongzhi, Ruan Yuan, Chen Changqi, The second year of Daoguang (1822). Image credit Zhongguo Fangzhi Ku

latitude. They also used hypsographic methods in expressing topography, such as hachuring, hill shading, and contouring. Local gazetteers during the Qing contain a large number of maps, which were generally made by local scholars. LoGaRT was used to identify all the gazetteer maps drawn with Western techniques with which a database was created to chart changes in the number of maps and the spatial distribution of gazetteers with these new maps. Particular attention was given to similarities and differences between gazetteer maps of different areas in the same historical period, the potential social and technical reasons for these similarities and differences, and the spread and application of Western cartographical technology in these maps.

Administrative maps from Guangdong provincial gazetteers were used to demonstrate the scientific dissemination of modern cartography and survey methods. Five Guangdong administrative maps from provincial gazetteers in the Qing dynasty were identified by searching LoGaRT. The first and second were created in the Kangxi period, neither of which contained longitude and latitude lines. The third one (see Figure 11), with longitude and latitude lines, was published in the Daoguang period, taking the longitude through Beijing as the prime meridian. Each grid is one degree, and each grid is equal to $250 \mathrm{li}$. Yet it is not accurate, especially in the Leizhou 雷州 and Qiongzhou 琼州 regions according to the Historical Atlas of China, and in fact according to a local gazetteer it was made without field measurements. Where, then, did the latitude and longitude data come from? The mapmaker, Li Mingche, was a 


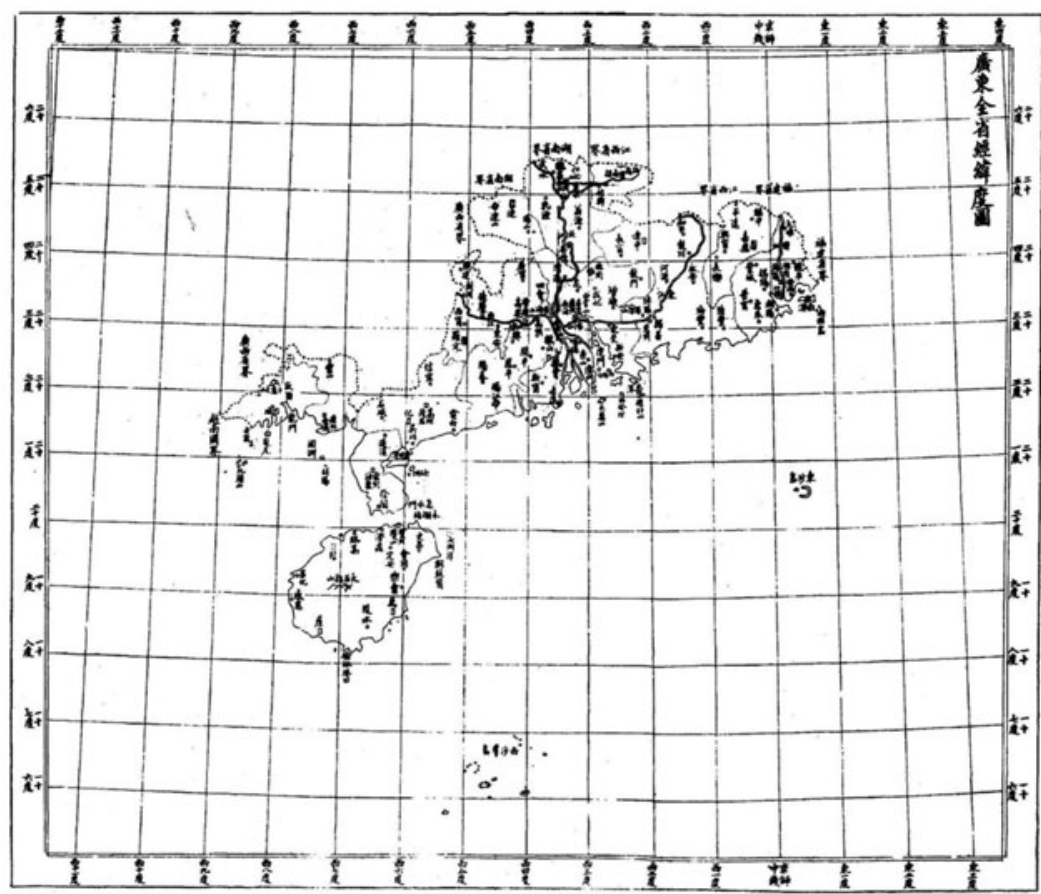

Figure 12. (Xuantong) Latitude and Longitude Map of Guangdong Province. (Xuantong) Guangdong Yudi Quantu, Guangdong Staff Section surveyed and mapped. The first year of Xuantong (1909). Image acquired from Zhongguo Difangzhi Congshu

Daoist priest skilled in astronomy, calendrical calculations, and arithmetic. His book Yuantian Tushuo 圖天圖說, which included two world maps, mentions map projection, longitude, and latitude. Possibly, he acquired knowledge of longitude and latitude from Kunyu Quantu 坤輿全圖 (1760), made by the Jesuit Benoist Michael (蒋友仁).

The accuracy of the fourth map, from the Tongzhi period, had significantly improved. By then the national survey data from the Kangxi and Qianlong periods was accessible to the general public through Ding Quzhong's 丁取忠 Latitude and Longitude Table (輿地 經緯度里表, 1861). The geographical data in this fourth map came from previous maps, books, interviews, and field measurements. Chen Li 陳澧1810-1882) and Zou Boqi 鄒伯奇 (1819-1869) were the mapmakers. Chen was a famous scholar in Guangdong and selfeducated in literature, geography, mathematics, and music. Zou also studied physics, geography, and math on his own and created the first camera in China. Zou had a good understanding of globe-shaped Earth theory and had participated in drawing Huangyu quantu 皇輿全圖, which adopted the tangent conic projection.

The last map (see Figure 12) was drawn during the Xuantong period. According to the local gazetteer, in addition to citing previous books, most geographical coordinates came from a sizeable field survey team: nine people were responsible for mapping, twelve were in charge of the survey, two translated Western maps, and four collected and organized the maps. They had different backgrounds. One group had studied the Four Books and Five Classics in traditional schools and had also studied astronomy, arithmetic and geography. A second group had learned Western surveying and cartography in new schools or 
overseas. For examples, Huang Lunsu graduated from Fuzhou Shipyard, Zhong Jincheng studied in the United States, Pan Yingqi graduated from Shixue College (實學館). A third group was trained in professional Western-style surveying and mapping techniques. Gu Chao, Zou Jin, and Lao Yingan had been involved in the process of settling a boundary dispute between China and Vietnam. From this we see the gradual introduction on modern cartography from the Daoguang period to the end of Qing dynasty.

\title{
Access to Logart
}

Although LoGaRT was developed as software to work with any collection of digital local gazetteers, it currently links to only the Zhongguo fangzhi ku from Erudition (Airusheng 愛如生) that is housed at the Berlin State Library. This dataset currently includes 3,999 local gazetteers, with some four million scanned pages, dating from the Tang dynasty through the early twentieth century. This accounts for roughly half of known extant gazetteers. Because this requires a special license, currently only MPIWG affiliates are entitled to use LoGaRT during their affiliation periods. We have been exploring ways to extend the access to LoGaRT, and we are planning on releasing a LoGaRT instance with open access contents in the spring of $2020 .{ }^{12}$ In the future we will release LoGaRT as a stand-alone software package, allowing any institution to install it and link it with collections of digital local gazetteers for which they have rights.

\section{Using Philologic For Digital Textual and Intertextual Analyses of the Twenty-Four Chinese Histories 二十四史}

Jeffrey Tharsen and Clovis Gladstone

doi:10.1017/jch.2020.27

\begin{abstract}
What does it mean to be able to study Chinese history at scale? What methods, tools, and approaches will allow us to understand Chinese history and historiography from a larger perspective over the longue durée, including linguistic, philosophical, ethnographic, and literary concerns? In this article we present what we feel is one potential key to answering these questions and provide an overview of the utility and value of harnessing this framework for text-based historical research as a means to expand one's scholarship to virtually limitless scales.
\end{abstract}

\footnotetext{
${ }^{12}$ This Open LoGaRT will contain around 400 titles of local gazetteers from the Harvard Yenching Library rare book collection. We thank Chiang Ching-kuo Foundation and the Max Planck Society for their funding to digitize this set of local gazetteers as searchable full texts.

Jeffrey Tharsen, University of Chicago, email: jcarlsen@uchicago.edu and Clovis Gladstone, University of Chicago, email: clovisgladstone@uchicago.edu
} 